precipitate coma and sudden death, as in the cases reported by Wallis et al. ${ }^{12}$

While the early signs are still reversible, the damage may be biochemical and invisible. Nevertheless, typically at necropsy there are focal neuronal lesions with congestion and haemorrhages in the medial parts of the thalamus, the hypothalamus, hippocampus, mamillary bodies, and periaqueductal grey matter in the mid-brain. These lesions may extend to the floor of the 4th ventricle and vagal nuclei, causing terminal hypotension and respiratory failure. Their characteristic focal distribution may indicate the parts which are most sensitive to the deficiency, particularly as transketolase, a thiaminedependent enzyme, loses its activity in the pontine tegmentum more rapidly than in other areas.

The important messages, then, are that the WernickeKorsakoff syndrome is preventable, can be diagnosed during life, and treatment with thiamine is most effective in the early stages. The condition is more common than generally realised and should be suspected and treated more often than hitherto; but would it not be better still-as Victor $e t$ al ${ }^{14}$ concluded in 1971-to intensify public health measures for the control of alcoholism and, possibly, to fortify foodstuffs with thiamine?

1 Neuburger, K, Virchows Archiv für pathologische Anatomie und Physiologie, 1936, 298, 68 .

2 Riggs, H E, and Boles, R S, Quarterly fournal of Studies on Alcohol, 1944, 5, 361 .

3 Campbell, A C P, and Biggart, J H, Fournal of Pathology and Bacteriology, $1939,48,245$.

1 Campbell, A C P, and Russell, W R, Quarterly Fournal of Medicine, $1941,10 \mathrm{NS}, 41$.

S Peters, R A, Lancet, 1936, 1, 1161.

- Zimmerman, H M, Yale Journal of Biology and Medicine, 1939, 12, 23.

7 Alexander, L, American fournal of Pathology, 1940, 16, 61.

- Ferraro, A, and Roizin, L, Transactions of the American Neurological Association, 1941, 67, 177.

9 de Wardener, H E, and Lennox, B, Lancet, 1947, 1, 11.

19 Spillane, J D, Nutritional Disorders of the Nervous System, Chapter 5. Edinburgh, Livingstone, 1947.

11 Harper, C, Fournal of Neurology, Neurosurgery, and Psychiatry, 1979, 42, 226.

12 Wallis, W E, Willoughby, E, and Baker, P, Lancet, 1978, 2, 400.

13 Ebels, E J, Lancet, 1978, 2, 781.

14 Victor, M, Adams, R D, and Collins, G H, The Wernicke-Korsakoff Syndrome. Oxford, Blackwell Scientific, 1971.

15 Cala, L A, et al, Australian and New Zealand fournal of Medicine, 1978, 8, 147.

\section{Pesticidal diabetes}

Man's success in the rat race of evolution has depended in part on his manipulation of the environment to his own advantage; and in an age when he has put mice into space the devastation caused by rodent-transmitted epidemics is easily forgotten. The Black Death (1348), for instance, killed one in three of the population in England, who, despite having heard of its westerly progression through Europe, were defenceless against the plague.

Rats occupy only one part of the arena of environmental medicine, but the emergence of "super-rats," resistant to the poison warfarin, caused considerable alarm. Among the toxic agents developed as an answer was - $\mathrm{N}$-3-pyridylmethyl $\mathrm{N}$-p-nitrophenyl (PNU), introduced into the United States in July 1975. The LD50 had been shown to be $4.75 \mathrm{mg} / \mathrm{kg}$ for rats, $710 \mathrm{mg} / \mathrm{kg}$ for chickens, and $2000-4000 \mathrm{mg} / \mathrm{kg}$ for rhesus monkeys, with little or no secondary toxicity in cats and dogs. ${ }^{1}$ These figures suggested that "non-target animals," including man, should be relatively safe, but hopes were dashed by seven human deaths due to accidental ingestion of contaminated rice in Korea. ${ }^{2}$ In 18 recorded poisonings in the United States there were five deaths, attributed to diabetic ketoacidosis, intestinal perforations, cardiac arrhythmias, and pneumonitis. ${ }^{3}$ Some children treated promptly with gastric lavage recovered without sequelae, ${ }^{3}$ but in most cases survivors have developed ketosis-prone diabetes mellitus and severe autonomic neuropathy. ${ }^{4}$

Early symptoms of poisoning with PNU include nausea, vomiting, abdominal pain, mental confusion, chest pain, dysphagia, cardiac arrhythmias, and pneumonitis. ${ }^{4}$ Severe orthostatic hypotension, loss of bladder reflexes, and peripheral polyneuropathy occur later. ${ }^{5}$ Serum amylase concentrations have been reported to be raised. ${ }^{45}$ The diabetic hyperglycaemia may remit for a short period and so be missed. ${ }^{4}$

The chemical structure of PNU is not unlike that of streptozotocin and alloxan, both of which are used to induce diabetes in animal studies. Streptozotocin depresses nicotinamide-adenine dinucleotide, and nicotinamide (niacinamide) has been shown to protect animals against its diabetogenic effect if administered before or even up to two hours after the poison. ${ }^{6}$ This protection also occurs in animals given PNU, provided the nicotinamide is given within an hour of intoxication. ${ }^{7}$

Rationally, therefore, nicotinamide should act as a specific antidote in poisoning with $\mathrm{PNU}-$ in conjunction with gastric lavage and symptomatic treatment of the diabetes, arrhythmias, and pneumonitis. The dose of nicotinamide is, however, still uncertain. One patient (weighing $70 \mathrm{~kg}$ ) given $500 \mathrm{mg}$ six hourly showed no signs of liver damage even after several weeks. ${ }^{3}$ Doses of $3.0 \mathrm{~g}$ have been given intravenously over 24 hours to patients with acute pellagra without undue effects, though in one case liver damage occurred in a patient who had taken $3.0 \mathrm{~g}$ daily for 18 months. ${ }^{8}$ An initial dosage of $3.0 \mathrm{~g}$ by intravenous infusion over the first 24 hours followed by $500 \mathrm{mg}$ six hourly seems reasonable and relatively safe, even though this is considerably less than the $250-500 \mathrm{mg} / \mathrm{kg}$ needed in rats to inhibit the diabetogenic action of streptozotocin given at a dose of $50 \mathrm{mg} / \mathrm{kg} .{ }^{9}$ Pending further studies, we do not know how long such treatment should be given. Nicotinic acid has also been tried as an antidote, ${ }^{4}$ but since it is more toxic in man, ${ }^{810}$ and in animals protects only against alloxan and not streptozotocin, ${ }^{11}$ its routine use cannot be recommended.

The neurological effects of poisoning with PNU are of great theoretical interest. Claude Bernard's observations of diabetes after puncture of the fourth cerebral ventricle have been followed by the discovery that acetylcholine stimulates the secretion of insulin, and conversely that increased sympathetic activity or electrical stimulation of the ventromedial hypothalamic nucleus increases the secretion of glucagon and exacerbates any tendency to diabetes. ${ }^{12}$ Now a single compound has been found to cause both severe autonomic neuropathy and diabetes, possibly by the reduction in concentrations of nicotinamide-adenine dinucleotide in the brain $^{13}$ and pancreas. ${ }^{14}$ Might this be the link between the brain and diabetes? Could the patient described by Miller $e t a l$, who produced C-peptide in response to arginine, ${ }^{3}$ have simply lost a compensatory neurological drive to those beta cells which survived the poisoning, and thereby have developed overt diabetes?

1 Peardon, D L, Pest Control, 1974, 42, 14, 16, 18, 27.

${ }^{2}$ Chemical Engineering News, 1975, 53, 8.

${ }^{3}$ Miller, L V, Stokes, J D, and Silpipat, C, Diabetes Care, 1978, 1, 73.

4 Pont, A, et al, Archives of Internal Medicine, 1979, 139, 185.

5 Prosser, P R, and Karam, J H, Fournal of the American Medical Association, 1978, 239, 1148. 
- Lazarus, S S, and Shapiro, S H, Diabetes, 1973, 22, 499.

${ }^{7}$ Deckert, F W, et al, Federation Proceedings, 1977, 36, 990.

${ }^{8}$ Winter, S L, and Boyer, J L, New England Fournal of Medicine, 1973, 289, 1180 .

- Dulin, W E, and Wyse, B M, Proceedings of the Society for Experimental Biology and Medicine, 1969, 130, 992.

10 Wade, A, ed, Martindale. The Extra Pharmacopoeia, 27th edn, p 1691. London, Pharmaceutical Press, 1977.

11 Ganda, O M P, Rossini, A A, and Like, A A, Diabetes, 1976, 25, 595.

12 Williams, R H, Textbook of Endocrinology, 5th edn, p 519. London, W B Saunders, 1974.

13 Schein, P S, Proceedings of the Society for Experimental Biology and Medicine, 1969, 131, 517.

14 Gunnarsson, R, Berne, C, and Hellerström, C, Biochemical fournal, 1974, $140,487$.

\section{Wellcome Museum of the History of Medicine}

Since 1934, the extensive medical museum and library founded by Sir Henry Wellcome have been housed together at the Wellcome Institute in Euston Road. In 1972, acting on the advice of their History of Medicine Panel chaired by the late Lord Cohen of Birkenhead, the Wellcome trustees decided to create an international centre for research into the history of medicine. They proposed setting up an academic unit to foster undergraduate and postgraduate teaching as well as research. To make this development financially possible, the trustees were advised that they would need to find a new home for the museum collection, and they took legal advice on the possibility of offering it on indefinite loan to the Science Museum.

The Science Museum had several advantages: a prime site attracting over 3 million visitors a year; increased gallery space; a considerable library of its own; and its skill in cataloguing, evaluating, and displaying objects. After detailed negotiations the transfer was announced on 22 June 1976 by the Minister for the Arts, Education, and Science. Dr Brian Bracegirdle was appointed keeper of the new department at the Science Museum, to be entitled the Wellcome Museum of the History of Medicine. Dr Bracegirdle, an educationalist and biologist, is a specialist in the history of medicine, his current research relating to the history of microscopy and histology.

To make the museum collections more widely known to scholars and the medical profession, the trustees appointed Dr Christopher Lawrence to the staff of the Wellcome Institute, to be Wellcome medical historian at the Science Museum. Dr Lawrence's special interest is the history of diagnostic instruments in the general evolution of recent medical technology.

Since the new Wellcome Museum of the History of Medicine at the Science Museum began its work on 1 April 1977 a staff of over 30 people, partly funded by the Wellcome trustees, has been engaged. Much of its work is concerned with cataloguing items accepted from the trustees to standards suitable for eventual computer retrieval. This transfer of objects may take a further five years. To date, while the staff has been building up in both numbers and expertise, over 12000 items have been dealt with and trial computer runs evaluated.

Meanwhile, as the trustees had intended, academic activity has expanded in the Euston Road building. A Wellcome academic unit for the history of medicine has been established, composed of institute staff and those working in the unit of the history of medicine, which is housed in the department of anatomy and embryology of University
College London, with contributions from senior members of the Wellcome Museum. The close association of the institute with the college means that members of the Wellcome academic unit can have honorary appointments at University College London and can supervise candidates for higher degrees. The Wellcome academic unit, which is based on the institute's library, has five staff members, whose combined skills cover classical medicine, Arab medicine, the mediaeval and Renaissance periods, and the 18th and 20th centuries. An extensive and increasingly popular programme of undergraduate teaching courses is offered in University College London and in the University of London at large, including the intercalated BSc in the history of medicine. Thesis and dissertation candidates are supervised, while research into many aspects of the history of medicine, both scientific and social, is being carried out by members of the institute's staff and a series of visiting research fellows and students from various parts of the world.

The new galleries at the Science Museum total 16000 square feet, and for the present much of the permanent staff's time is spent on the arrangement of the displays. When the galleries open, in November 1980, they will cater for audiences ranging from young schoolchildren to postgraduate students. The lower gallery will concentrate on vivid models and reconstructions, with simple labelling intended for the younger and non-specialist visitor. The upper gallery will have more detailed displays. The Wellcome trustees intend to put a further large sum into the galleries, making a truly joint venture with the Science Museum. The Wellcome Museum is intended to expand its 20th century collection considerably, becoming an archive of contemporary medical objects, and it should become a centre for the academic study and teaching of the history of medical technology.

\section{Splenectomy for massive splenomegaly}

The normal spleen weighs only about $150 \mathrm{~g}$. Some enlargement is a feature of many diseases, but the spleen becomes massively enlarged (over $1500 \mathrm{~g}$ ) comparatively rarely. Massive splenomegaly may occur in the chronic leukaemias, myelofibrosis, the lymphomas, malaria, kala-azar, the storage diseases, and portal hypertension; and splenic cysts may occasionally cause massive enlargement. The diagnosis of splenomegaly may be confirmed by plain abdominal radiographs, radionuclide scans, or ultrasound; and occasionally splenic arteriography may be justifiable.

Splenectomy should not be undertaken in such patients just because the spleen is massively enlarged. Sometimes the sheer size of the organ may have caused symptoms such as pain or a feeling of heaviness; but the development of haematological problems, and especially hypersplenism, is a more convincing indication for operation. In some patients splenectomy may be required for diagnosis. Removal of a big spleen is associated with a greater morbidity and mortality than routine splenectomy, so that the surgeon needs to consider in detail his operative technique, and whether, for example, to infuse adrenaline into the splenic artery to reduce splenic size and the problem of bleeding. Individual surgeons also differ ${ }^{12}$ about the value of early ligation of the splenic artery, which is said to allow easier control of bleeding.

The benefits of splenectomy were clearly shown in a series 